\title{
The Revolutionary spirit of the Contemporary Women writers of India.
}

\author{
${ }^{1}$ Dr. Itishri Sarangi, ${ }^{2} \mathrm{Ms}$. Yajnaseni Mukherjee \\ ${ }^{1,2}$ Assistant Professor KIIT University Bhubaneswar
}

\begin{abstract}
The feminist always tries to restore the tarnished image of the woman and glorify it. One evident trait among all the contemporary women writers in Indian writings in English is the revolutionary spirit with which they strive to write. Their writings are an explosion of suppressed desires and pent up feelings that have long been gathered. Women writers have proved that their writings are serious and require attention. They handle things efficiently balancing tradition and womanhood. To be a feminist is to be able to create a specific feminine mode of writing, fighting for the liberation of womenfolk in subjugation and all those forces within and outside the society that troubled the neat categories of the family and mutilated the feminine side of a woman. The infiltration of the western culture gave a serious blow to the Indian traditional life and women who epitomes were upholding the family regime gradually became transformed into women in search of their sole identities and in search of a liberated independence.
\end{abstract}

The feminist always tries to restore the tarnished image of the woman and make it glorified. One evident trait among all the contemporary women writers in Indian writings in English is the revolutionary spirit with which they strive to write. It is an explosion of pent up feelings that has long been gathered. Women writers have proved their stuff to be more serious and that which requires attention. They handle things efficiently balancing tradition and womanhood. To be a feminist is to be able to create a feminine mode of writing,fighting for the liberation of women and all that crap that destroyed the family and mutilated the feminine side of a woman. The infiltration of the western culture gave a serious blow to the Indian traditional life.

The work of Indian women writers is significant in making the society aware of the women's needs and demands in providing a medium for self expression and assertion. Traditionally, the work of Indian women has been underrated and devalued on mere assumption about the superior worth of the male. Majority of the contemporary Indian women writers like Anita Desai, Shashi Despande have focused on the psychological sufferings, oppressions of the frustrated housewife whose only option was to suppress the storm within, the inevitable existential predicament of women in a male dictated society. The neglected women as characters in their novel attempt for better way of life mentally and physically. We clearly see a "creative release of feminine sensibility" in the novels of Anita Desai. (Rao 50)

Cultural clash suffered by the women swinging between two cultures has also been a prominent theme in the writings of the Indian women writers - a state of inbetweeness which was explored by Kamala Das and Jumpa Lahiri with utmost care and accuracy. They have described the apathy towards women with simple and stunning frankness. Their writings act as windows to view the unexplored female psyche which is unfortunately beyond the reach of most of the male understanding. "Feminine and masculine represents social construct- pattern of sexuality and behavior imposed by cultural and social norms."(Singh 3)

Authors like Anita Desai have chosen to depict the prevailing problems and issues faced by the women in today's male dominated society. In Voices in the City there is a detailed depiction of the middle class intellectuals of the contemporary Kolkata and in Cry the Peacock, there is a slow and continuous growth of mental imbalance in the psyche of the wife who fails to adjust with the hard core practical world of her husband. She eventually feels rejected, in such a demoralized state of mind that she kills her husband out of frustration. Anita Desai, a concerned social Visionary and a keen observer of the contemporary society has tried to explore the psychological aspect of her protagonists in context to the prevailing day to day conflicts in man and women relationship. "The hallmark of Desai's fiction is to focus on the inner experience of life." (Kanwar 7)

Today's Novels act as a mirror reflecting the protest and the outburst of the suppressed feelings of women which has never been taken care for ages. Shashi Despande's novel That Long Silence begins with the sentence "To achieve anything, you've got to be ruthless." Despande's The Long Silence revolves around the ongoing problems and predicament of the middle class house hold. Her writings are like case studies of women full of reality. Her women are real flesh and blood characters from whom one cannot take one's eyes of. One can visualize with clarity, the struggle and trauma they go through in their relationships pertaining to their surroundings, their society, their families, their children and especially with their men. In The Long Silence 
Despande has depicted the Character of Jaya as a educated typical middle class house wife with lots of love and affection for her children who is dutiful and respectful to her husband and in-laws but neglected when it comes to her feelings and emotions. Her sincerity, honesty and dedication are not recognized by anyone who ultimately sinks her into silence. Her silence is symbolic to most women in the world who are unable to express themselves as an individual. This silence gives her way to search for Identity. She says, "Worse than anything else had been the boredom of the unchanging pattern, the unending monotony"(p.4). She desperately wanted a change and fought for it.

"Despande teaches women to fight the silence and express themselves. Deshpande is not unconcerned about Indian reality in respect of the lot of women, but she is not a strident and militant kind of feminist who sees the male as the sole cause of all her problems. Her concern, in fact, is nothing less than the human predicament. As a chronicler of human relationships she is superb. The interplay between tradition and modernity and tensions generated by it has been faithfully presented. Deshpande does not offer readymade solutions, for she believes, in literary writing "one does not pose a problem and present a solution. It's not maths. The value based fabric of life that she projects are of great significance." (Literature and Gender 171)

Shobha De has gone a step ahead of the man-woman relationship in marriages. Women ought to discuss about their priorities and prerogative. $20^{\text {th }}$ century saw a phenomenal change in woman's writing. De has moved away from the usual regular track and has actually made a serious analysis of the manwoman relationship. In Socialite Evenings De has described in the background of Bombay high profile society, the lives of rich house wives spending their lives in loveless marriages whose self centered husbands treat them more like commodities than human beings. The so called hi-fi wives are used by their husbands more for social respectability than for love. De has vociferously and strongly advocated that a woman ought to tell her partner not to take her for granted, she should assert for her rights and boldly speak to her man regarding her main concern and choices. She should make her point clear to one and all that she also has the right to be happy like anyone else.

Sex is implied more explicitly in Socialites Evening (1989) by De which describes the erotic sex lives of the high society in Mumbai. De expresses the innermost desire of wishes of modern women, the women who were brought up in conservative environments turns up as enlightened women with strong determination and freedom along with their responsibilities, where the middle class always wants to have the lifestyle of the elites. These women novelist write about women who try to fit themselves in the shiny version of globalization. They talk about people who have lived their life in east as well as west and their emotional results.

Kamala Das is a confessional poet whose treatment of female sexuality is free from any sense of guilt happens to be the basic ingredient of her writing style. Her main theme revolved around love, its betrayal and the subsequent anger. Her frankness in relation to sexual matters expressed with dignity is remarkable. She focused on the marriage, motherhood, women's concerns to their bodies and sexual explorations in the backdrop of traditional Indian society. Das considered male as beast full of lust and ego which is instrumental in crushing the identity of women ruthlessly.

When I asked for Love, not knowing what else to ask For, he drew a youth of sixteen into the Bedroom and closed the door, He did not beat me But my sad woman body felt so beaten. The weight of my breasts and womb crushed me. I shrank pitifully.

A glimpse of Das's special edge of sensuous and passionate love, total involvement and unconditional honesty for the lover is discussed in her poem The Looking Glass

\section{"Gift him all,}

Gift him what makes you woman, the scent of

Long hair, the musk of sweat between the breasts."

Das's poetry provides an excellent opportunity for study of the psyche of the loveless and deprived lives of married woman who are not only deprived of freedom of expression but are also restricted to the extent of being chained within the ambit of the husband's household which is depicted in The Old Play House.

You planned to tame swallow to hold her

in the long summer of your love so that she would forget

Not the raw seasons alone, and the homes left behind, but

Also her nature, the urge to fly and the endless

Pathways of the sky...

Cowering

Beneath your monstrous ego I ate the magic loaf and

Became a dwarf I lost my will and reason, to all

You're Questions I mumbled incoherent replies 
The image of women in recent writings has undergone a sea change. Women writers have moved away from the traditional, age old portrayal of self-sacrificing women towards conflicting female protagonists searching for identity and self respect. Unquestionably, Shoba De happens to be India's one of the top writers in revealing various facets, confusions, agony and frustrations of modern women. In her famous book, Spousethe Truth about Marriage, she elaborately describes about the real colors of, the urban institution of marriage. It is a sort of guide book dealing with, as to why a marriage is either successful or a disaster. Through her strong, bold and individualistic style she has to her credit of having created almost a new language "Hinglish" wherein one can experience an excellent blend of english and hindi with good timing by virtue of permutation and combination. She communicated with her readers point blank in an entirely new language without any ambiguity.

De's first novel Socialite Evenings points at the wounds of the society from which the blood of agony and frustration trickle down spreading on the self-centered male dominated society demanding for justice, basically it focuses on the life style of Mumbai high society, depicting the life styles of the fed up affluent ladies hanging on the loveless marriages encouraging them to choose the option of extra marital affairs in order escape from their sadistic husbands whose only interest for their wives is for social respectability than love. The novel gives its readers an opportunity to visualize about the high profile parties and the false spiritual leaders who filled the vacuum of the superficial Mumbai elite life. De has factually described the results of senseless infiltration of western culture into the lives of elite Mumbaites which led to erosion of Indian traditional culture. Karuna, the protagonist of this story is similarly dumped into loneliness and is fed up with her life and husband, in order to get rid of from such sad circumstances, she starts writing a Memoir. Through her perseverance, tenacity, she becomes an active socialite and eventually uses her new found prominence to achieve a respectable position in the materialistic society.

Second Thoughts by De illustrates the unnecessary social compulsions forced on the Contemporary Women in the name of traditions and culture grossly exhibiting utter indifference for their desires and freedom "males indifference to the desires and freedom of women left to suffer in loneliness". Though De faced lot of criticism for some her Novels like Socialite Evenings for her erotic and unusual contents which shocked the traditional elements of the society but surely it touched the right nerve with many people especially the women in India. Although, a novel it reflects various aspects of De's own rise to fame and some consider it to be partially autobiographical. Irrespective of various opinions, acceptances and rejections, undoubtedly, she stands as a strong pillar for women- power, women emancipation in the society and as an undisputed advocate for the women world as a whole.

Women writers were mostly known to write about their enclosed domestic spheres. They were ranked below the male writers who supposedly dealt with 'weightier themes'. As they started venturing out of their enforced comfort zones and charting virgin territories of extra-marital affairs, new found love, the sight and quest for an identity, the so called male bastion stating falling apart. Women now desirous of proving themselves and their acumen, walked shoulder to shoulder with men proving themselves equal and even better sometimes. Thus emerged women literature and contemporary women writers were no more the "second sex". The social contructs of man and woman as separate entities in the binary oppositional structure fell apart and women no more subjugated to the whims and fancies of the male society. She had emerged from the cocoon of her existence, the beautiful butterfly ready to take on the world. Her writings in English- the language of the cosmopolitan society gave her wings to fly. The woman was ready to explore the pathos, the humility, the subjugation of her existence and lend it a voice which would prove to the world at large that she was an equal, in some instances she could challenge the suzerainty of man and emerge victorious. The woman as a writer had appeared on the world scenario and contemporary woman's writing is a tribute to the resurrection of women power and talent.

\section{References}

[1] Singh, Sushila, "Outlining Feminist Literary Criticism” in Feminism and Literature: New Point of View, ed. By K.K.Sharma, K.K Pub., Delhi, 1996 p-3

[2] Rao, A.V.Krishna, The Indo-Anglican Novel and the Changing Tradition, Mysore:Rao and Raghavan, 1972 p.50

[3] Kanwar, Asha, The Novels of Virginia Woolf and Anita Desai, A comparative Study, Prestige Books New Delhi, 1991, p.7

[4] Despande, Shashi, That Long Silence: 1988 (New Delhi: Penguin India Ltd., 1989.

[5] (Reference to this text is on the paper)

[6] Despande Shashi , Literature and Gender, Directorate of Distance Education

[7] Maharshi Dayanand University2004, Maharshi Dayanand University, ROHTAK 